\title{
Nematode Parasites of Red Sokoto Goats (Capra hircus) Slaughtered at Trans-Amadi and Rumuokoro Abattoirs, Rivers State, Nigeria
}

\author{
Daisy Abere \\ Department of Animal and Environmental Biology, Rivers State University, P.M.B. 5080, \\ Port Harcourt, Nigeria \\ Tel: +234-8032250128Ｅmail: abere.daisy@gmail.com
}

\begin{abstract}
Belema Robert
Department of Animal and Environmental Biology, Rivers State University, P.M.B. 5080, Port Harcourt, Nigeria

Tel: +234- 8099712639 Email: robertbelema40@gmail.com

Chidinma C. Amuzie (Corresponding author)

Department of Animal and Environmental Biology, Rivers State University, P.M.B. 5080, Port Harcourt, Nigeria

Tel: +234-803 $6729346 \quad$ Email: nmaamuzie@gmail.com

Godfrey C. Akani

Department of Animal and Environmental Biology, Rivers State University, P.M.B. 5080, Port Harcourt, Nigeria
\end{abstract}

Tel: +234-8063435298_Ｅmail: gakanina2000@yahoo.com

Received: Feb. 3, 2020 Accepted: Mar. 2, 2020

doi:10.5296/jbls.v11i1.16603 URL: https://doi.org/10.5296/jbls.v11i1.16603 


\section{Abstract}

Helminths are common parasitic fauna of goats. This study was aimed at identifying and quantifying the gastrointestinal helminth parasites of Red Sokoto goats slaughtered at Trans-Amadi and Rumuokoro abattoirs, Rivers State, Nigeria. Fifty intestinal tracts were examined at each location accounting for a total of 100 samples from both locations. Samples were weighed and dissected; direct microscopy was used to examine samples for adult helminths and test-tube floatation technique was used to examine organic matter from samples for parasite eggs. Nematodes were identified using keys and fixed in $70 \%$ alcohol. Prevalence and mean intensity of infection were computed; product moment correlation and Student t-tests were used for statistical analysis. Two nematode parasites were identifiedHaemonchus contortus and Trichuris ovis. In Trans Amadi, prevalence and mean intensity of infection were $46.0 \%$ and 13 parasites/infected host, respectively for $H$. contortus, and $54.0 \%$ and 11 parasites/infected host for T. ovis. In Rumuokoro, prevalence of $38.0 \%$ and $52.0 \%$ were computed for $H$. contortus and $T$. ovis, respectively, while the mean intensity were 6 and 8 parasites/infected host, respectively for $H$. contortus and $T$. ovis. Single infection with Trichuris ovis was higher (30\% Trans Amadi; 34\% Rumuokoro) than either single infection with $H$. contortus or double infection with both parasites. There was a significant correlation between the parasite burden and intestinal mass at Trans-Amadi ( $\mathrm{r}_{48}=0.33, \mathrm{P}_{0.05}=0.279$ ), but not at Rumuokoro $\left(\mathrm{r}_{48}=0.10, \mathrm{P}_{0.05}=0.279\right)$. The total prevalence and prevalence of single and double infection at both locations did not differ significantly $\left(\mathrm{t}_{3}=0.93, \mathrm{p}=0.21\right)$. Agricultural extension and meat inspection services should be carried out regularly to educate farmers on the symptoms, impacts, treatment and management of helminth parasites.

Keywords: Helminth parasites, abattoir, correlation, Haemonchus, Trichuris

\section{Introduction}

Gastrointestinal parasitic infections constitute a world-wide problem for both small and large-scale farmers, but their impact is greater in Sub-Saharan Africa due to the availability of a wide range of agro-ecological factors suitable for diversified hosts and parasite species (Fikru et al., 2006).

Impacts of nematode parasites may be undetected but in severe infections animal health, growth and productivity are reduced. They may also result in death of infected hosts. This is most common in free range goats that graze in contaminated fields (Keyyu et al., 2005). Urquhart et al. (1996) stated that the causes of helminth parasite infection in goats included factors such as the presence of infective stages on pasture, increase in the susceptibility of hosts, inclusion of susceptible hosts to the herd, and wrong administration of antihelminthic drugs or the development of parasite-resistance strains.

Goats are important sources of protein and income to households in Nigeria (Nwosu et al., 2007; Hassan et al., 2011). The West African dwarf goats are typically reared in southern parts of Nigeria while the Red Sokoto breed is farmed in the northern parts of the country. Their productivity is limited by parasite infections, including gastro-intestinal helminthes (Keyyu et al., 2005; Fikru et al., 2006). Gastrointestinal parasites limit ruminant production 


\section{Macrothink}

through decreased growth rate, weight loss, diarrhea, anorexia and sometimes anaemia (Akerejola et al., 1999; Colley et al., 2001; Keyyu et al., 2005).

The prevalence of gastrointestinal helminth parasites is influenced by agro-climatic conditions such as sunlight, temperature, rainfall, humidity and soil moisture (Fakae, 1990; Chiejina, 2001). Under optimal conditions of high humidity and warm temperature especially during the rainy season in the tropics, worm burdens increase leading to outbreaks of parasitic gastroenteritis in goats and sheep (Khajuria et al., 2013).

This study was aimed at identifying and quantifying the gastrointestinal helminths of Red Sokoto goats slaughtered at Trans-Amadi and Rumuokoro abattoirs, Port Harcourt, Rivers State. The hypothesis that prevalence of helminth parasites would be same at both locations was tested.

\section{Materials and Methods}

\subsection{Sample Location}

This research was conducted using the gastro-intestinal tracts of Red Sokoto goats purchased

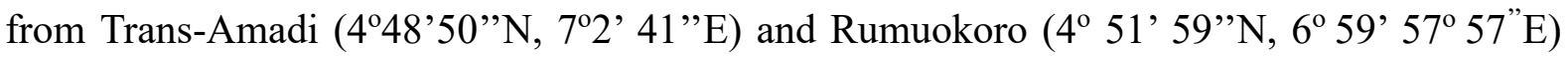
abattoirs of Rivers State, Nigeria. Both locations are situated in the Niger Delta region of the country. A map showing the sample locations is presented in Figure 1. 


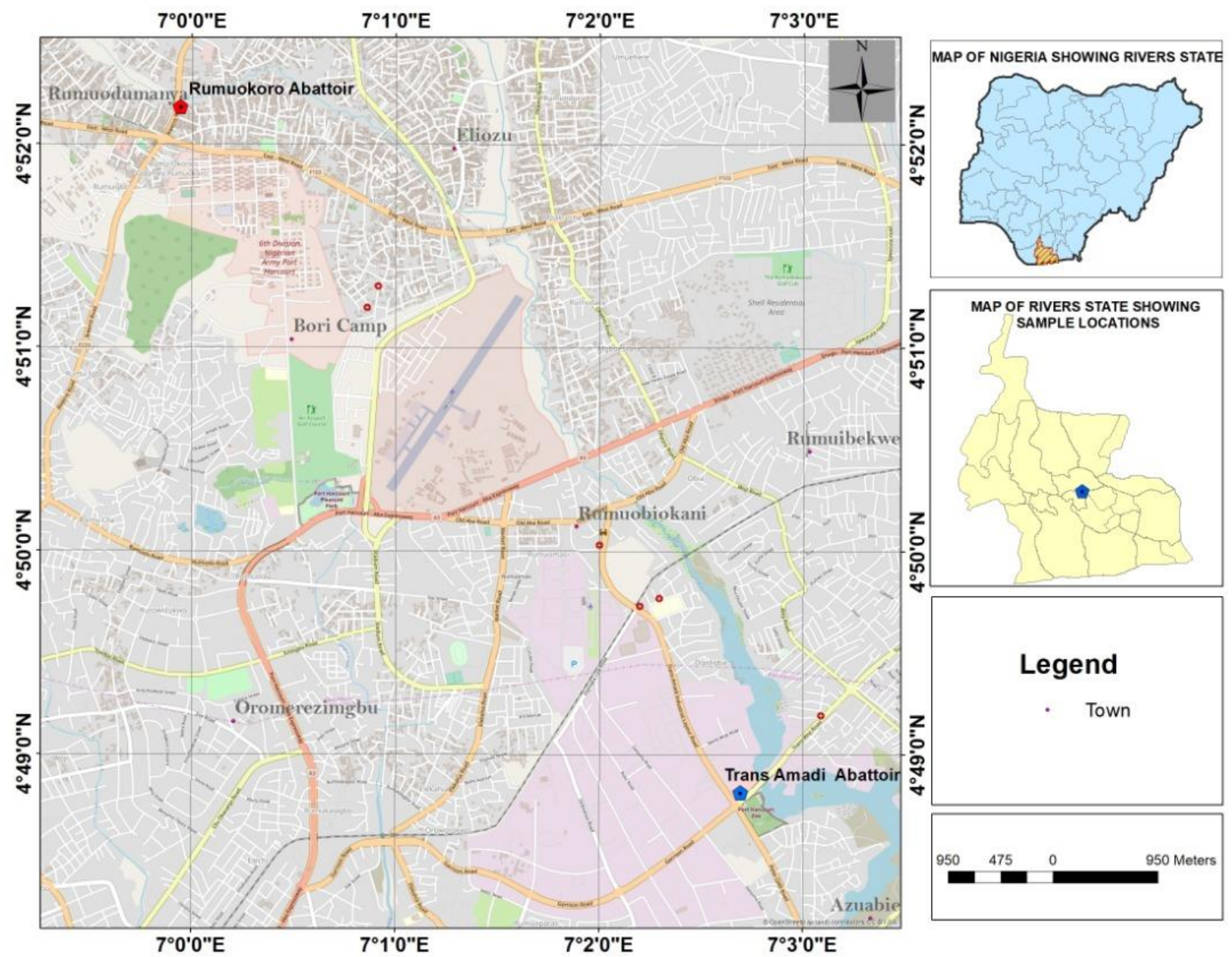

Figure 1. Map showing position of Trans-Amadi and Rumuokoro abattoirs, Rivers State, Nigeria

\subsection{Sample Collection}

The gastro-intestinal tract of Red Sokoto goats were purchased weekly from the abattoir in numbers of one to five until the sample size of 50 was reached for each location. Sample collection lasted from February to April, 2019, during the dry season. Relevant information on the sex and age of the hosts was noted, and the purchase was packed in separate bags according to sex and transported to the Parasitology and Entomology Laboratory, Rivers State University.

Mass of the intestines were determined using a weighing balance (Denver Instrument, Model: TP-512A). Sex of hosts were determined by morphological examination before slaughter.

\subsection{Laboratory / Post-mortem Investigation}

Each sample was tagged and the intestine was weighed. The content of the stomach was emptied into a plastic container and examined. The intestine was sectioned into the abomasum (small intestine) and omasum (large intestine). Each section was dissected longitudinally to expose its contents and release parasites in a $0.92 \%$ saline solution.

Test tube floatation technique was used to examine organic matter from the samples for 
parasite eggs. A saturated salt solution was used; and this was obtained by adding $400 \mathrm{~g}$ of $\mathrm{NaCl}$ to $1,000 \mathrm{~mL}$ of distilled water (Pouillevet et al., 2017). $1 \mathrm{~g}$ of sample was thoroughly mixed in $15 \mathrm{ml}$ of the saturated solution, sieved through a net of $2 \mathrm{~mm}$ mesh size. The filtrate was poured into a test tube which was filled up with more of the solution. The test tube was kept standing in a rack and covered with a cover slip. It was allowed to stand for 20 minutes after which the cover slip was removed, placed on a microscope slide and observed under a light microscope.

\subsection{Parasite Fixation, Identification and Quantification}

Nematode parasites were extended in hot water and fixed in $70 \%$ alcohol. These were cleared in lactophenol and viewed under the microscope for identification.

Parasites were identified using keys from Soulsby (1982). Photographs of representative parasites were taken using a digital camera attached to a compound microscope. Parasite statistical measures of prevalence and mean intensity were computed according to Bush et al., (1997). They were computed generally and according to sex.

\subsection{Statistical Analysis}

Product moment correlation was used to test for significant correlation between parasite burden and intestinal mass in each location. Values were compared with statistical tables under the degrees of freedom.

Student t-test was used to test for significant differences in the prevalence of parasite infection between sexes in both locations. This test was also used to test for significant differences in total prevalence as well as values of single and double infection at both locations. Significance was taken at $\mathrm{P}<0.05$.

\section{Results}

Two species of nematodes were identified as infecting the goats examined from both locations. They were the Barber pole worm, Haemonchus contortus and the whipworm, Trichuris ovis. Haemonchus contortus was recovered from both the stomach and intestine, but $\mathrm{T}$. ovis was found only in the intestinal region of infected specimens from both locations.

The mass of the intestine of the hosts examined ranged from 480 to $1013 \mathrm{~g}$ in Trans-Amadi and 550 to $1474 \mathrm{~g}$ in Rumuokoro. There was a statistically significant correlation between the parasite burden and the intestinal mass at Trans-Amadi ( $\mathrm{r}_{48}=0.33, \mathrm{P}_{0.05}=0.279$ ). Product moment correlation, $\mathrm{r}$, between both factors at Rumuokoro was not significant $\left(\mathrm{r}_{48}=0.10\right.$, $\mathrm{P}_{0.05}=0.279$ ).

\subsection{Prevalence of Infection in Goats from Trans-Amadi Abattoir, Port Harcourt, Nigeria}

Haemonchus contortus and Trichuris ovis were recovered from the goats from this location. Of the fifty hosts examined, thirty-eight were infected giving a total prevalence of $76 \%$. Intensity of infection with $H$. contortus ranged between 1 and 44 parasites per infected host, and $T$. ovis between 1 and 49 worms per infected host. Forty-six male and four female goats were examined in this location and parasite prevalence and intensity be gender of host 
specimens are presented in Table 1 . All female hosts were infected while about $74 \%$ of the male specimens were infected.

Twenty-one male hosts were infected with Haemonchus contortus and twenty-three infected with $T$. ovis. Two female hosts were infected with $H$. contortus while all four female hosts were infected with T. ovis (Table 1).

Table 1. Parasite infection of Red Sokoto Goats at Trans-Amadi abattoir, Rivers State, Nigeria

\begin{tabular}{|c|c|c|c|c|c|c|}
\hline \multirow[t]{2}{*}{ Gender } & \multirow[t]{2}{*}{$\begin{array}{l}\text { Number } \\
\text { examined }\end{array}$} & \multirow[t]{2}{*}{$\begin{array}{l}\text { Range of } \\
\text { mass of } \\
\text { intestine } \\
(\mathrm{g})\end{array}$} & \multirow[t]{2}{*}{$\begin{array}{l}\text { Number } \\
\text { uninfected } \\
(\mathrm{P} \%)\end{array}$} & \multirow[t]{2}{*}{$\begin{array}{l}\text { Number } \\
\text { infected } \\
(\mathrm{P} \%)\end{array}$} & \multicolumn{2}{|c|}{$\begin{array}{l}\text { Prevalence } \\
\text { infection, \%; } \\
\text { Mean intensity } \\
\text { infection; } \\
\text { (Range) }\end{array}$} \\
\hline & & & & & H. contortus & T. ovis \\
\hline Male & 46 & $550-1013$ & $12(26.09)$ & $34(73.9)$ & $\begin{array}{l}45.65 \\
13.6 \\
(1-44)\end{array}$ & $\begin{array}{l}50.0 \\
11.5 \\
(1-49)\end{array}$ \\
\hline Female & 4 & $680-890$ & $0(0.0)$ & $4(100.0)$ & $\begin{array}{l}50.0 \\
11.0 \\
(4-18)\end{array}$ & $\begin{array}{l}100.0 \\
7.3 \\
(2-11)\end{array}$ \\
\hline Total & 50 & & $12(24.0)$ & $38(76.0)$ & $\begin{array}{l}46.0 \\
13.3 \\
(1-44)\end{array}$ & $\begin{array}{l}54.0 \\
11.0 \\
(1-49)\end{array}$ \\
\hline
\end{tabular}

\subsection{Prevalence of Infection in Goats from Rumuokoro Abattoir, Port Harcourt, Nigeria}

The same nematode parasites, Haemonchus contortus and Trichuris ovis, were recovered from the goats in this location. Like in the Trans-Amadi abattoir, more males $(n=40)$ than females $(n=10)$ were slaughtered and examined for parasites. Thirty-six host specimens were infected accounting for a prevalence of $72.0 \%$.

Intensity of infection with $H$. contortus ranged between 1 and 31 parasites per infected host, and T. ovis between 1 and 47 worms per infected host. Parasite prevalence and intensity by gender of host specimens are presented in Table 2 . A higher percentage of female $(80 \%)$ than male $(70 \%)$ hosts were infected. Fifteen male hosts were infected with Haemonchus contortus and nineteen infected with $T$. ovis. Four female hosts were infected with $H$. contortus while seven female hosts were infected with T. ovis (Table 2). 
In both locations, prevalence of infection was higher in female than in male hosts. Similarly, infection with $T$. ovis was more prevalent than that of $H$. contortus. The total prevalence of parasite infection in male and female specimens of both locations was tested for statistical differences. Student t-tests showed no significant differences $\left(t_{1}=1.48, p=0.19\right)$.

Table 2. Parasite infection of Red Sokoto Goats at Rumuokoro abattoir, Rivers State, Nigeria

\begin{tabular}{|c|c|c|c|c|c|c|}
\hline \multirow[t]{2}{*}{ Gender } & \multirow[t]{2}{*}{$\begin{array}{l}\text { Number } \\
\text { examined }\end{array}$} & \multirow[t]{2}{*}{$\begin{array}{l}\text { Range of } \\
\text { mass of } \\
\text { intestine } \\
\text { (g) }\end{array}$} & \multirow[t]{2}{*}{$\begin{array}{l}\text { Number } \\
\text { uninfected } \\
(\mathrm{P} \%)\end{array}$} & \multirow[t]{2}{*}{$\begin{array}{l}\text { Number } \\
\text { infected } \\
(\mathrm{P} \%)\end{array}$} & \multicolumn{2}{|c|}{$\begin{array}{l}\text { Prevalence } \\
\text { infection, \%; } \\
\text { Mean intensity } \\
\text { infection; } \\
\text { (Range) }\end{array}$} \\
\hline & & & & & $\begin{array}{l}H . \\
\text { contortu }\end{array}$ & T. ovis \\
\hline \multirow[t]{3}{*}{ Male } & 40 & $550-1211$ & $12(30.0)$ & $28(70.0)$ & 37.5 & 47.5 \\
\hline & & & & & 6.8 & 6.4 \\
\hline & & & & & $(1-31)$ & $(1-28)$ \\
\hline \multirow[t]{3}{*}{ Female } & 10 & 669-1139 & $2(20.0)$ & $8(80.0)$ & 40.0 & 70.0 \\
\hline & & & & & 4.0 & 11.1; \\
\hline & & & & & $(1-6)$ & $(1-47)$ \\
\hline \multirow[t]{3}{*}{ Total } & 50 & & $14(28.0)$ & $36(72.0)$ & 38.0 & 52.0 \\
\hline & & & & & 6.2 & 7.7 \\
\hline & & & & & $(1-31)$ & $(1-47)$ \\
\hline
\end{tabular}

\subsection{Single and Co-infection of H. contortus and T. ovis in Red Sokoto Goats Slaughtered at} Trans-Amadi and Rumuokoro Abattoirs, Rivers State, Nigeria

Single and double infection with both parasites were very common in both locations. At Trans-Amadi, a higher prevalence of hosts were infected with only Trichuris ovis $(30.0 \%)$, followed by double infection with both parasites (24.0\%), and lastly single infections with only Haemonchus contortus (22.0\%) (Table 3$)$.

A similar trend was observed in host specimens from Rumuokoro: $34.0 \%$ of the hosts were infected with only $T$. ovis; $20.0 \%$ with only $H$. contortus and $18.0 \%$ with both parasites (Table 3). The total prevalence as well as values of single and double infection at both 
locations were also tested for statistical differences which were not significant $\left(t_{3}=0.93\right.$, $\mathrm{p}=0.21$ ). Photomicrographs of the parasites are shown in Plates $1-3$.

Table 3. Prevalence (P\%) of H. contortus and T. ovis in Red Sokoto goats slaughtered at Trans-Amadi and Rumuokoro abattoirs, Rivers State, Nigeria

\begin{tabular}{llllll}
\hline Location & $\begin{array}{l}\text { No. } \\
\text { hosts } \\
\text { examined }\end{array}$ & $\begin{array}{l}\text { Total no. of } \\
\text { hosts } \\
\text { infected }\end{array}$ & $\begin{array}{c}\text { No. of hosts infected with } \\
\text { single infection }\end{array}$ & $\begin{array}{l}\text { No. of hosts } \\
\text { infected } \\
\text { both parasites }\end{array}$ \\
\hline & & & $\begin{array}{l}\text { Haemonchus } \\
\text { contortus }(\mathrm{P} \%)\end{array}$ & $\begin{array}{l}\text { Trichuris } \\
\text { ovis }(\mathrm{P} \%)\end{array}$ & $\begin{array}{l}\text { H. contortus }+ \\
\text { T. ovis }\end{array}$ \\
Trans-Amadi & 50 & 38 & $11(22.0)$ & $15(30.0)$ & $12(24.0)$ \\
Rumuokoro & 50 & 36 & $10(20.0)$ & $17(34.0)$ & $9(18.0)$ \\
Total & 100 & 74 & $21(21.0)$ & $32(32.0)$ & $21(21.0)$ \\
\hline
\end{tabular}

A

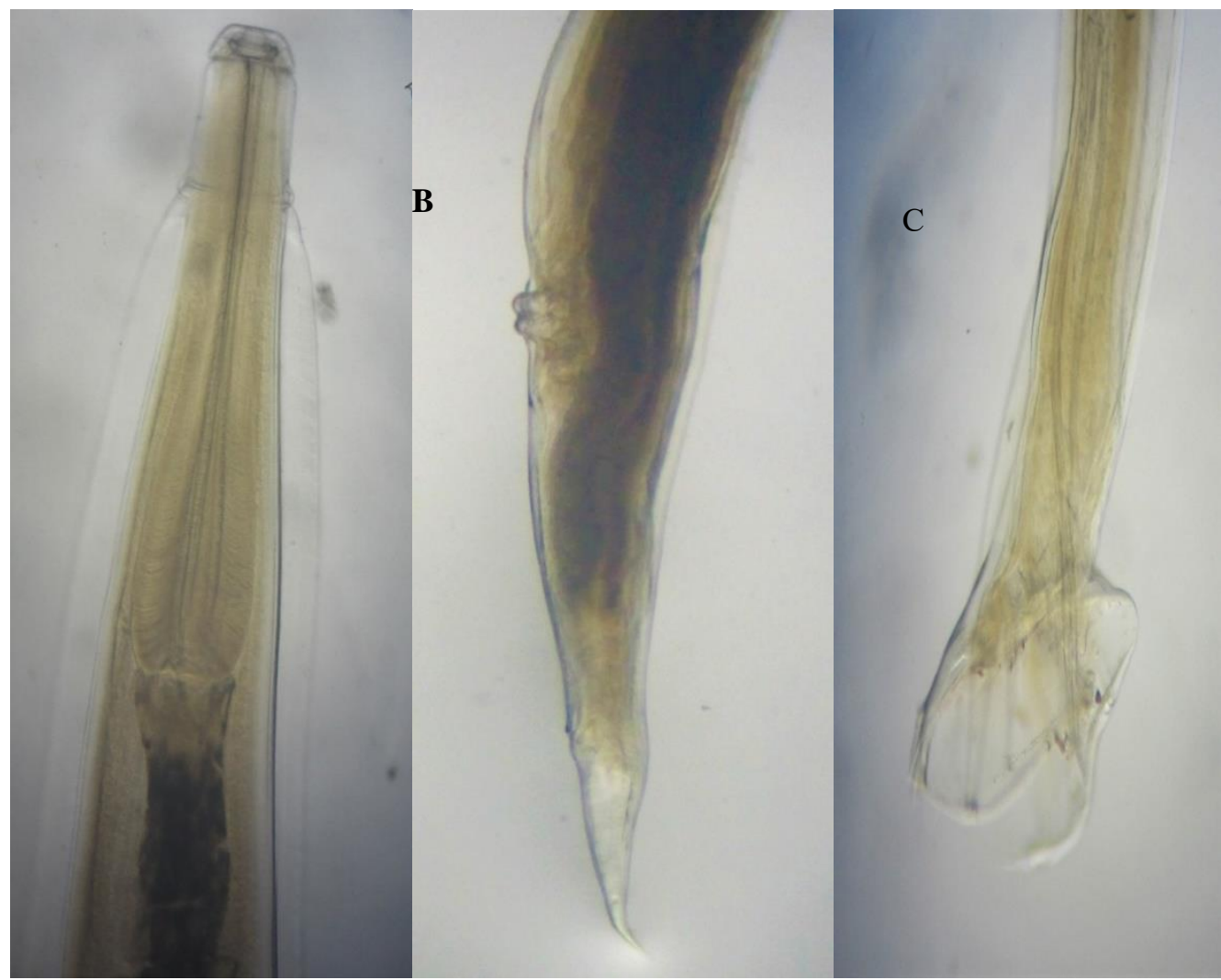

Plate 1. Photomicrograph of Haemonchus contortus (X10)

Key: $\mathrm{A}=$ Anterior region; $\mathrm{B}=$ Female posterior region; $\mathrm{C}=$ Male posterior region . 


\section{Macrothink
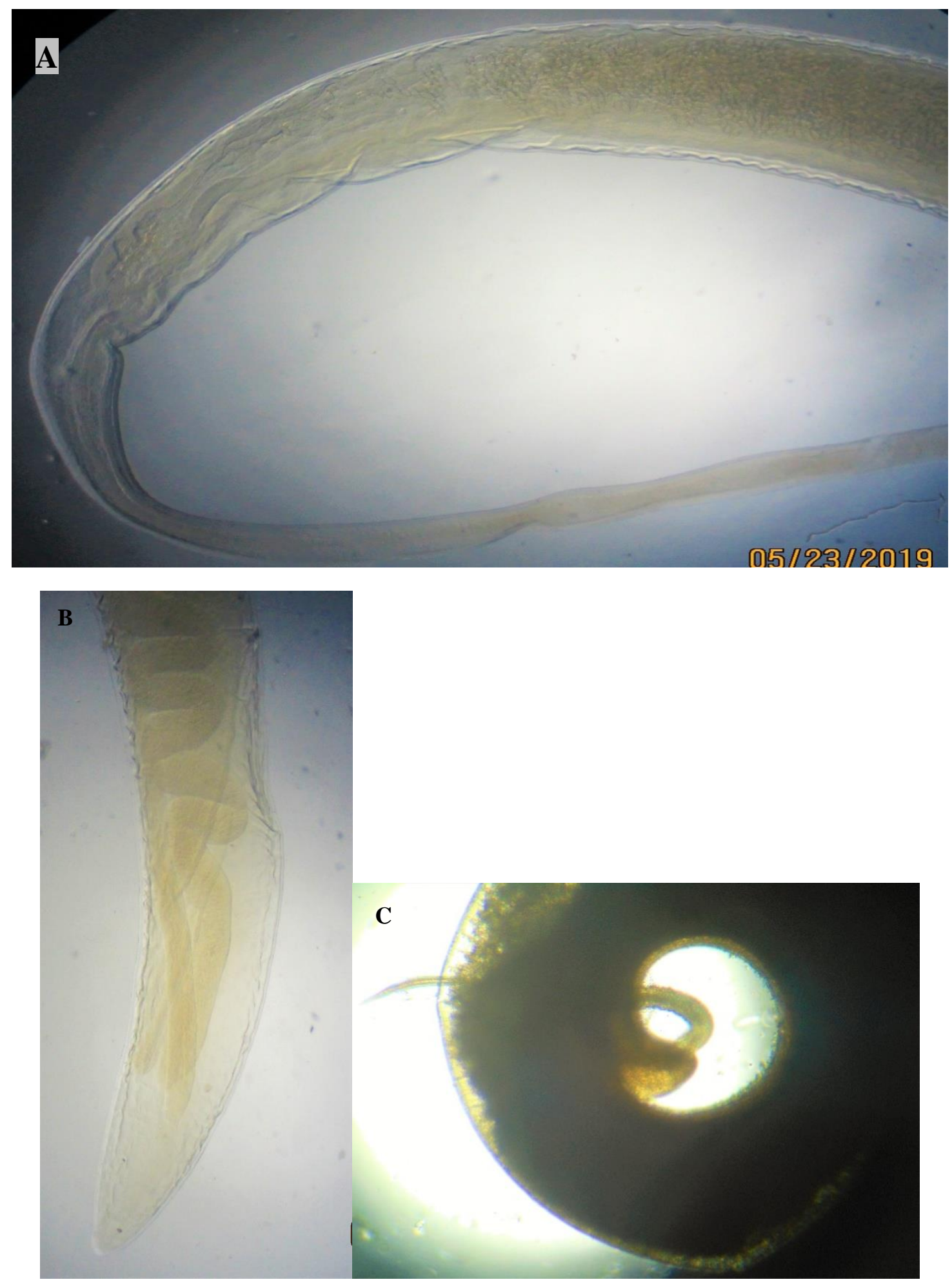

Plate 2. Photomicrograph of Trichuris ovis (x10)

Key: $\mathrm{A}=$ Anterior region; $\mathrm{B}=$ Posterior region of female $T$. ovis $; \mathrm{C}=$ Posterior region of male $T$. ovis showing the spicule 


\section{$\triangle$ Macrothink}

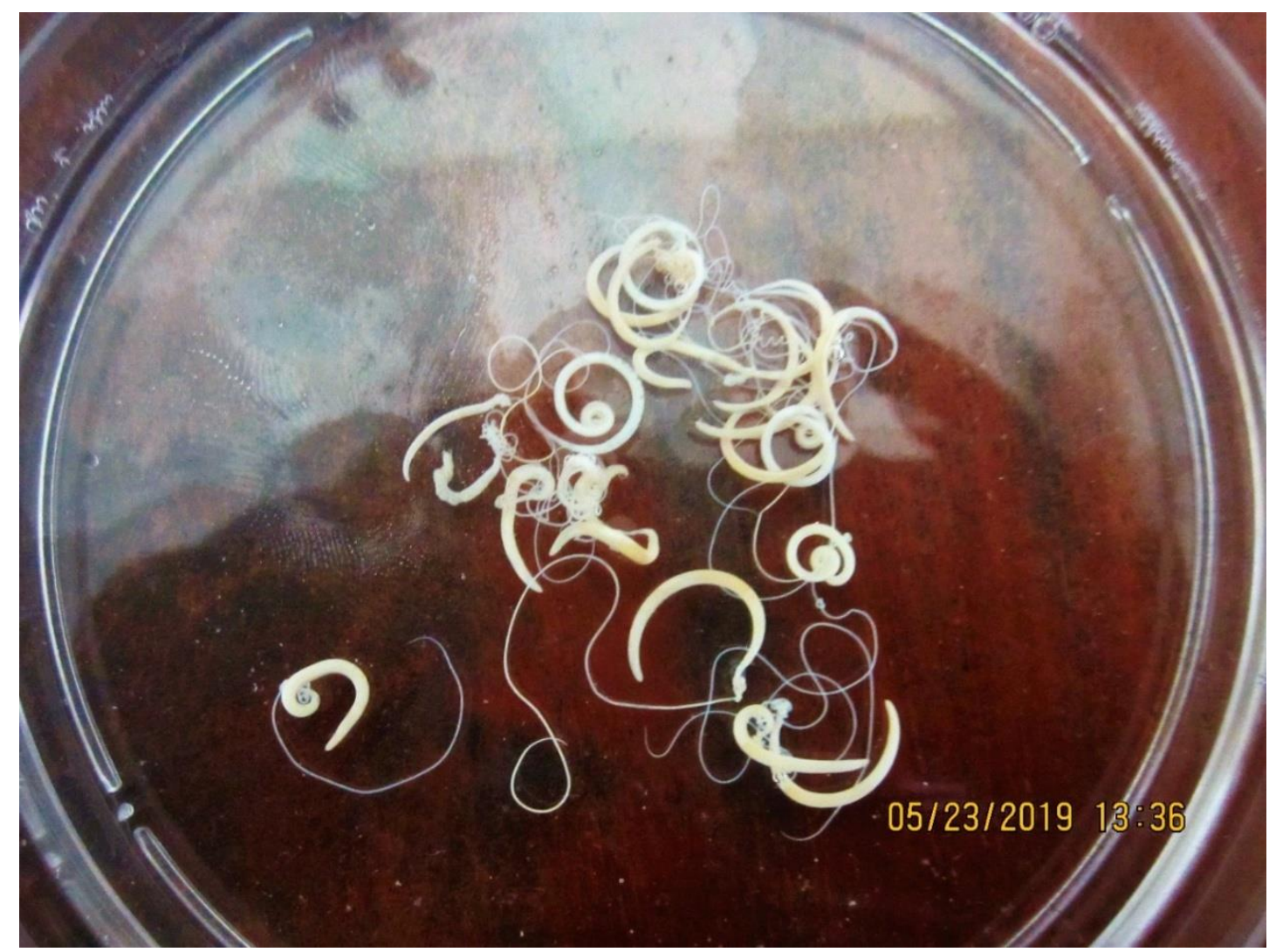

Plate 3. Appearance of Trichuris ovis on a Petri dish

\section{Discussion}

Helminth parasites including cestodes, trematodes and nematodes are common parasitic fauna of goats. In the present research on Red Sokoto goats of Trans Amadi and Rumuokoro abattoirs, only nematodes ( $H$. contortus and $T$. ovis) were encountered. The factors contributing to the fewer parasites encountered include collection of samples during the dry season and restriction of investigation to the intestinal tract, excluding the liver, bile ducts, and gall bladder. Research has proven that higher worm species and burdens are recorded during the rainy season (Fakae, 1990; Chiejina, 2001) and when several other organs are examined (Ikpeze and Nzemeka, 2009; Amadi et al., 2012).

The nematodes, $H$. contortus and $T$. ovis, recovered from the goats investigated in this research are common infections of goats under field conditions (Ikpeze and Nzemeka, 2009). In several other reports, nematode parasites were usually more abundant than other helminth groups (Ikpeze and Nzemeka, 2009; Amadi et al., 2012; Eke et al., 2019). This observation is related to the life cycle of nematodes which does not require an intermediate host, and eggs and infective larval stages can often be picked up while the animals are grazing. This is especially the case for strongylid parasites of small ruminants (including $H$. contortus, Teladorsagia circumcincta, Trichostrongylus spp., T. ovis, Oesophagostomum spp. etc) (Sissay, 2007). Trematodes and cestodes, on the other hand, often require an intermediate host in order to complete their life cycle.

In the present research, nematode infection was more prevalent in the female hosts than in the 
male conspecifics. In specimens from the Trans-Amadi abattoir, 100\% of the females were infected while about $74 \%$ of the males were infected, and in those from Rumuokoro abattoir, $80 \%$ and $70 \%$ prevalence was recorded for female and male goats, respectively. Statistical tests were not significant. In their own research, Amadi et al. (2012) reported a higher prevalence of helminth infection in male goats than in the female conspecifics, but noted that differences were not statistically significant. An interesting observation made by these authors was that nematode parasites were more prevalent in females (96.8\%) than in males (83.1), while trematode infection was more prevalent in male $(76.2 \%)$ than in female $(65.6 \%)$ hosts; they reported that cestode infection was about same for both sexes, $6.7 \%$ in females and $6.9 \%$ in females. Differences in observation of sex influence on prevalence of nematode parasites may be based on the exposure of the animals to parasite infective stages. Where both male and female animals graze together, they have equal chances of infection (Dappawar et al., 2018), although impaired immunity is also contributory (Khajuria et al., 2013).

In the present research, also, T. ovis was more prevalent and with a higher worm burden than H. contortus. However, several other authors (Sissay, 2007; Ikpeze and Nzemeka, 2009; Nuruzzaman et al., 2012; Eke et al., 2019) reported H. contortus as having the highest worm burden when compared with other parasites recovered in their research. The higher prevalence of $T$. ovis over $H$. contortus reported in this research could be due to the presence of eggs in the grazing area and farm house. The larvae of $H$. contortus may not be as successful as the eggs of T. ovis in establishing infection due to environmental factors such as humidity and temperature to which they are more susceptible (O'Connor et al., 2006; Sissay, 2007).

\section{Conclusion}

The prevalence of gastrointestinal nematode parasites in Red Sokoto goats from Trans Amadi and Rumuokoro abattoirs, Rivers State, Nigeria, is highlighted. Animal grazing areas should be cleaned regularly to reduce infection by nematodes. Deworming should also be carried out regularly following veterinary protocols.

\section{References}

Akerejola, O. O., Van Veen, T. W. S., \& Njoku, C. O. (1999). Ovine and caprine diseases in Nigeria a review of economic losses. Bulletin of Animal Health and Production in Africa, 27(1), 65-70.

Amadi, A. N. C., Avoaja, D. A., \& Essien. E. J. (2012). Epidemiology of helminth parasites of West African Dwarf Goat (Capra hircus) in Umuariaga in Ikwuano L.G.A, Abia State. Journal of Applied Science and Environmental Management, 16(4), 359-362.

Bush, A. O., Lafferty, K. D., Lotz, J. M., \& Shostak, A. W. (1997). Parasitology meets ecology on its own terms: Margolis et al. Revisited. Journal of Parasitology, 83(4), 575-583. https://doi.org/10.2307/3284227 
Chiejina, S. N. (2001). The epidemiology of helminth infections of domesticated animals in the tropics with emphasis on fasciolosis and parasitic gastroenteritis. Perspectives on Helminthology. Plymouth, UK: Science Publishers Inc.

Colley, D. G., LoVerde, P. T., \& Savioli, L. (2001). Infectious disease: medical helminthology in the 21st century. Science, 293(5534), 1437-1438. https://doi.org/10.1126/science.1060733

Dappawar, M. K., Khillare, B. S., Narladkar, B. W., \& Bhangale, G. N. (2018). Prevalence of gastrointestinal parasites in small ruminants in Udgir area of Marathwada. Journal of Entomology and Zoology Studies, 6(4), 672-676.

Eke, S. S., Omalu, I. C. J., Ochaguba, J. E., Urama, A. C., Hassan, S. C., Otuu, C. A., \& Okafor, I. D. (2019). Prevalence of gastrointestinal parasites of sheep and goats slaughtered in Minna modern abattoir, Niger State, Nigeria. Journal of Animal Science and Veterinary Medicine, 4(2), 65-70. https://doi.org/10.31248/JASVM2019.131

Fakae, B. B. (1990). The epidemiology of helminthosis in small ruminants under the traditional husbandry system in eastern Nigeria. Veterinary Research Communications, 14, 381-391. https://doi.org/10.1007/BF00343216

Fikru, R., Teshale, S., Reta, D., \& Yosef, K. (2006). Epidemiology of gastrointestinal parasites of ruminants in western Oromia, Ethiopia. International Journal of Applied Research and Veterinary Medicine, 4(1), 51-57.

Hassan, M. M., Hoque, M. A., Islam, S. K. M. A., Khan, S. A., Roy, K., \& Banu, Q. (2011). A prevalence of parasites in black Bengal goats in Chittagong, Bangladesh. International Journal of Livestock Production, 2(4), 40-44.

Ikpeze, O. O., \& Nzemeka, F. I. (2009). Gastrointestinal tract (GIT) helminth parasites of goat in Ibusa, Delta State, southern Nigeria. African Journal of Medical Sciences, 2(1), 20-23.

Keyyu, J. D., Kyvsgaard, N. C., Monrad, J., \& Kassuku, A. A. (2005). Epidemiology of gastrointestinal nematodes in cattle on traditional, small-scale dairy and large-scale dairy farms in I district, Tanzania. Veterinary Parasitology, 127, 285-294. https://doi.org/10.1016/j.vetpar.2004.10.014

Khajuria, J. K., Katoch, R., Yadav, A., Godara, R., Gupta, S. K., \& Singh, A. (2013). Seasonal prevalence of gastrointestinal helminths in sheep and goats of middle agro-climatic zone of Jammu province. Journal of Parasitic Diseases, 37(1), 21-25. https://doi.org/10.1007/s12639-012-0122-3

Nuruzzaman, M., Haque, M. H., Sarker, S., \& Begum, N. (2012). Abomasal nematodes in goats slaughtered at different Abattoir of Thakurgaon District, Bangladesh. Journal of Scientific Research, 4(2), 491-497. https://doi.org/10.3329/jsr.v4i2.7475

Nwosu, C. O., Madu, P. P., \& Richards, W. S. (2007). Prevalence and seasonal changes in the population of gastro-intestinal nematodes of small ruminants in the semi-arid zone of 
north-eastern Nigeria. Veterinary Parasitology, 44(1-2), 118-124. https://doi.org/10.1016/j.vetpar.2006.09.004

O'Connor, L. J., Walkden-Brown, S. W., \& Kahn, L.P. (2006). Ecology of the freeliving stages of major trichostrongylid parasites of sheep. Veterinary Parasitology, 142, 1-15. https://doi.org/10.1016/j.vetpar.2006.08.035

Pouillevet, H., Dibakou, S. E., Ngoubangoye, B., Poirotte, C., \& Charpentier, M. J. E. (2017). A comparative study of four methods for the detection of nematode eggs and large protozoan cysts in mandrill faecal material. Folia Primatologica, 88, 344-357. https://doi.org/10.1159/000480233

Sissay, M. M. (2007). Helminth parasites of sheep and goats in eastern Ethiopia: epidemiology, and anthelmintic resistance and its management. Doctoral thesis, Swedish University of Agricultural Sciences, Uppsala, Sweden.

Soulsby, E. J. L. (1982). Helminths, Arthropods and Protozoa of Domesticated Animals (7th Ed). London: The English Language Book Society and Ballière Tindall.

Urquhart, G. M., Armour, J., Duncan, J. L., Dunn, A. M., \& Jennings, F. W. (1996). Veterinary Parasitology (2nd ed). United Kingdom: Blackwell Science.

\section{Copyright Disclaimer}

Copyright for this article is retained by the author(s), with first publication rights granted to the journal.

This is an open-access article distributed under the terms and conditions of the Creative Commons Attribution license (http://creativecommons.org/licenses/by/4.0/). 